\title{
Pengelolaan Pertambangan dan Energi: Analisis dalam Perspektif Hukum Islam
}

\author{
Dr. H.Mispansyah,S.H.,M.H. \& Dr.Hj.Nurunnisa,S.H.,M.H. \\ Fakultas Hukum Universitas Lambung Mangkurat \\ Jln. Komplek AMD Permai Blok A18 No.359, Alalak Utara, Banjarmasin Utara, Banjarmasin, \\ Kalimantan Selatan, Indonesia. \\ Tel.Fax: (0511) 3305959 E-mail: ipan.shmh@gmail.com/nisa.shmh@gmail.com
}

\begin{abstract}
Indonesia is a state with rich natural resources in mining and energy, including coal mining. The presence of Law No. 4 of 2009 concerning Mineral and Coal Mining should contribute to the benefit (welfare) of society. The issue to be discussed in this paper is, how does the Islamic values find its legitimacy within the Law No. 4 of 2009? How actual mining management from the perspective of Islamic law? The objective of this research is to understand the essence of the Islamic values which contained in the Law No. 4 of 2009, and then to determine the mining management in the perspective of Islamic law. The outcomes of the research indicate that there is a correlation between Islamic values and the Law of Mineral and Coal Mining as maintenance value, conservation value, the value of harmony between natural resources, sustainability value, prosperity value as well as the value of fairness and balance. In addition, there is a Liberalism value which contained in the Law of Mineral and Coal Mining, so at this time, management of mining owned by domestic and abroad entrepreneurs. Mining and energy management in the perspective of Islamic law are grouped into three parties, namely assets which are public facilities, that if no man's land, there will be disputes in looking for. Then, this is a property that must be managed by the State, not managed private individuals or groups both domestic and abroad entrepreneurs.
\end{abstract}

Keywords: Energy; Islamic Law; Management; Mining

\begin{abstract}
Abstrak
Indonesia termasuk negara yang kaya raya dengan pertambangan dan energy, termasuk pertambangan batubara. Kehadiran Undang-Undang Nomor 4 Tahun 2009 tentang Pertambangan Mineral dan Batubara hendaknya memberi kontribusi kesejahteraan bagi masyarakat. Isu penelitian yang dikaji dalam tulisan ini adalah untuk menganalisis esensi hukum Islam yang terkandung dalam Undang-Undang Nomor 4 Tahun 2009? Bagaimanakah sebenarnya pengelolaan pertambangan dalam perpsektif Hukum Islam? Tujuan dari penulisan ini untuk menemukan nilai-nilai Islam yang terkandung dalam Undang-Undang Nomor 4 Tahun 2009, kemudian untuk mengetahui pengelolaan pertambangan dalam perspektif Hukum Islam. Hasil Pembahasan menggambarkan adanya Nilai Islam dalam Undang-Undang Nomor 4 Tahun 2009 seperti Nilai pemeliharaan, nilai konservasi, nilai harmonisasi antara sumber daya alam, nilai keberlanjutan, nilai kesejahteraan dan nilai keadilan dan keseimbangan. Disamping itu juga ada nilai Liberalisme yang dianut oleh UU ini sehingga saat ini pengelolaan pertambangan dimiliki oleh para pengusaha baik dalam dan luar negeri. Pengelolaan pertambangan dan energy dalam Islam dikelompokkan dalam 3 bagian yaitu pertama, harta yang merupakan fasilitas umum yang jika tidak ada akan terjadi sengketa dalam mencarinya, maka ini merupakan harta bersama yang harus dikelola Negara bukan dikelola individu/kelompok baik swasta dalam dan luar negeri.
\end{abstract}

Kata Kunci: Energi; Hukum Islam; Pengelolaan; Pertambangan 


\section{A. PENDAHULUAN}

Undang-Undang Dasar Negara Republik Indonesia Tahun 1945 Pasal 33 menegaskan bahwa :

(1) Perekonomian disusun sebagai usaha bersama berdasar atas azas kekeluargaan;

(2) Cabang-cabang produksi yang penting bagi Negara dan yang menguasai hajat hidup orang banyak dikuasai oleh Negara;

(3) Bumi, air dan kekayaan alam yang terkandung didalamnya dikuasai oleh Negara dan dipergunakan untuk sebesar-besarnya kemakmuran rakyat;

(4) Perekonomian nasional diselenggarakan berdasar atas demokrasi ekonomi dengan prinsip kebersamaan, efisiensi berkeadilan, berkelanjutan, berwawasan lingkungan, kemandirian, serta dengan menjaga keseimbangan kemajuan dan kesatuan ekonomi nasiona;

(5) Ketentuan lebih lanjut mengenai pelaksanaan pasal ini diatur dalam undangundang.

Undang-Undang Nomor 4 Tahun 2009 mengatur tentang Pengelolaan Pertambangan Mineral dan Batubara. Pada tahun 2001 pemerintah dan Dewan Perwakilan Rakyat melahirkan Undang-Undang Nomor 22 Tahun 2001 tentang Minyak dan Gas Bumi, UU ini menuai kritik karena dianggap menguntungkan pengusaha baik dalam dan luar negeri. Makna "dikuasi Negara" ini menjadi pembahasan baik dalam disertasi, tesis, skripsi, maupun pertemuan-pertemuan ilmiah. 12 Organisasi Kemasyarakatan mengajukan Judicial review terhadap UU Migas telah diputuskan oleh Mahkamah Konstitusi pada tanggal 13 November 2012, dengan putusan Nomor 36/PUUX/2012. Putusan Mahkamah Konstitusi mengabulkan sebagian dari permohonan uji materiil UU Migas. Salah satu dari putusan Mahkamah Konstitusi tersebut menyatakan bahwa BP Migas bertentangan dengan Undang-Undang Dasar Negara Republik Indonesia Tahun 1945 (UUD N RI 1945). Putusan tersebut sekaligus mengalihkan fungsi serta regulasinya kepada kementerian terkait. ${ }^{1}$

Pengaturan mengenai energi merupakan materi yang penting bagi kelangsungan hidup manusia. banyak aktivitas manusia yang memerlukan energi bagi kelancaran hidupnya. Energi berasal dari berbagai sumber, baik energi primer maupun sekunder. Indonesia merupakan Negara yang kaya dengan kekayaan alam yang melimpah, negeri yang dikenal sebagai Negara kaya sumber energi diantaranya: energi panas bumi (40\% cadangan dunia berada di Indonesia), energi matahari (Indonesia adalah Negara terpanjang berada di garis khatulistiwa yang dilewati matahari), energi gas alam yang sangat potensial mencapai 186,6 triliun kaki kubik, energy batubara selama 2005-2006

1 Santi Dwi Kartika. 2012. Putusan Mk Atas Uji Materi Uu Migas. https:// shantidk. wordpress.com/2012/12/12/putusan-mk-atas-uji-materi-uu-migas/diakses 15 Oktober 2013 
Indonesia menjadi Negara pengekspor batubara terbesar di dunia, cadangan yang ada mencapai 12 milyar ton. ${ }^{2}$

Potensi pertambangan batubara di Kalimantan Selatan sebesar 5 milyar ton sehingga disebut sebagai deposit batubara di Indonesia. Dalam Indonesia Mineral and Coal Statistics (IMCS), produksi batubara di Kalimantan Selatan, yang tercatat resmi dari tahun 2003 sebesar 46.116.289,80 ton dan meningkat pada tahun 2004 yaitu sebesar 54.540.977,16 ton, dan sebagian besar produksi batubara tersebut dihasilkan oleh perusahaan besar dengan modal asing (PMA) seperti PT.Arutmin dan PT.Adaro Indonesia. $^{3}$

Dalam bidang pertambangan emas, Indonesia juga dikenal sebagai Negara kaya dengan aturan-aturan yang menguntungkan investor Tahun 1967 Indonesia menarik PT Freeport Indonesia (FI) memulai Kontrak Karya generasi I (KK I) untuk konsesi selama 30 tahun. Pada tahun 1988 secara tidak diduga PT Freeport Indonesia menemukan deposit emas yang sangat besar di Grasberg diperkirakan mencapai 72 juta ton, kemudian mereka mengajukan pembaharuan KK selama 30 tahun dan bisa diperpanjang selama 10 tahun. PT.Freeport Indonesia bersama 6 perusahaan tambang lainnya mendapat Kontrak Karya V (KK V), berbeda dengan KK I produk utama PT FI adalah emas, bukan hanya tembaga. Menurut Econit, royalty yang diberikan FI ke pemerintah tidak berubah hanya 1 - 3,5 persen sehingga penerimaan pemerintah dari pajak, royalty dan deviden PT FI hanya US\$ 479 juta. Jumlah itu tentu masih sangat jauh dibandingkan pendapatan yang diperoleh PT FI sekitar US\$ 1,5 miliar (tahun 1996), yang di potong untuk mengembangan masyarakat papua (dulu Irian Jaya) sekitar US\$ 15 juta. ${ }^{4}$

Logika sederhana dengan potensi pertambangan mineral dan batubara yang melimpah tersebut, maka akan mendorong pertumbuhan ekonomi, produk industri yang kompetitif di pasar dan energi yang murah melimpah. Pembangunan akan berjalan pesat, mengentaskan kemiskinan, kesehatan dan pendidikan gratis sehingga dapat menghasilkan Sumber Daya Manusia yang berkualitas. Namun tidak semuanya mengikuti alur logika tersebut, yang terjadi pemadaman listrik khususnya di Kalimantan Selatan sebagai penghasil batubara yang menjadi enegri listrik, karena PT PLN memberi batubara dari perusahaan tambang.

Lahirnya Undang-Undang Nomor 4 Tahun 2009 tentang Pertambangan Mineral dan Batubara diharapkan dapat memberikan perubahan atas sumber kekayaan alam ini untuk kesejahteraan rakyat Indonesia. Berdasarkan latar belakang tersebut penulis mencoba membahasnya dalam perspektif Islam dengan rumusan masalah sebagai berikut: pertama, nilai Islam apakah yang terkandung dalam Undang-Undang Nomor 4 Tahun

${ }^{2}$ Lembaga Dakwah Kampus UNLAM dan Himpunan Mahasiswa Fisika FKIP UNLAM. 2008. "Analisis Potensi Kalimantan Selatan Dalam Peta Energi di Indonesia." Kalimantan Selatan Berdialog. Banjarmasin: Universitas Lambung Mangkurat Banjarmasin. hlm.1

${ }^{3}$ Ibid.

${ }^{4}$ Buletin Al- Islam. 2011. “Mengelola Sumber Daya Alam Secara Islami”. Edisi 75/Th.VIII. Jakarta: HTI Press. hlm.3 
2009? Kedua, bagaimanakah sebenarnya pengelolaan pertambangan dalam perpsektif Hukum Islam? Tujuan dari penulisan ini untuk menemukan nilai-nilai Islam yang terkandung dalam Undang-Undang Nomor 4 Tahun 2009, kemudian untuk mengetahui pengelolaan pertambangan dalam perspektif Hukum Islam.

\section{B. METODE}

Metode penelitian ini menggunakan penelitian hukum normatif yaitu metode penelitian kepustakaan, dengan pendekatan filosofis (philosofis Approach) yaitu pendekatan filsafat dalam hal ini untuk menemukan nilai Islam dalam Undang-Undang Pertambangan Mineral dan Batubara, dan pendekatan kedua adalah perbandingan ( comparative approach) dengan melihat pengelolaan pertambangan dalam perspektif Hukum Islam.

Bahan Hukum yang digunakan adalah baham hukum primer berupa UndangUndang Dasar 1945, Undang-Undang Nomor 4 Tahun 2009. Bahan hukum sekunder yait bahan hukum dalam bentuk tulisan baik Disertasi, tesis, skripsi, makalah, artikel dan lainlain yang menunjang bahan hukum primer. Bahan Hukum tersier adalah kamus, baik kamus bahasa Indonesia, Inggris, Arab maupun kamus hukum dan ensiklopedi lainnya. Bahan hukum tersebut di kumpulkan dan diinventarisir, dari hasil inventarisasi tersebut kemudian dipilah dan dibuat pemetaan mengenai nilai Islam dalam Undang-Undang Nomor 4 Tahun 2009, juga dibuat gambaran mengenai perspektif Hukum Islam mengatur pengelolaan pertambangan, setelah ditemukan nilai filosofis dan perbandingan dalam Hukum Islam kemudian ditarik suatu kesimpulan.

\section{ANALISIS DAN PEMBAHASAN}

\section{A. Nilai Islam dalam Undang-Undang Nomor 4 Tahun 2009}

Hukum Islam merupakan hukum yang hidup dalam masyarakat Indonesia khususnya bagi mereka yang beragama Islam, saat ini sistem hukum Islam dan hukum adat akan ditransformasikan menjadi bagian sistem hukum nasional. ${ }^{5}$

Muhammad Daud Ali mengatakan bahwa : "memang secara normatif hukum Islam harus mendapat tempat dalam pembangunan hukum kita, yaitu tertera dalam UUD 1945 Pasal 29 yang menjamin hukum agama bagi pemeluknya. Ali Said menyatakan disamping Hukum Adat dan Hukum Barat, hukum Islam merupakan salah satu komponen tata hukum Indonesia, menjadi salah satu sumber bahan baku bagi pembentukan hukum nasional. Hal ini juga sama dikemukakan oleh Ismail Saleh, menurut beliau hukum Islam memegang peranan penting dalam membentuk serta membina ketertiban sosial umat Islam, maka jalan terbaik yang dapat ditempuh adalah mengusahakan secara ilmiah adanya transformasi norma hukum Islam ke dalam hukum

\footnotetext{
${ }^{5}$ Sunaryati Hartono. 1988. Politik Hukum, Jakarta: YLBHI.hlm.62
} 
nasional. Sepanjang masih sesuai dengan dasar Negara dan UUD 1945 dengan keperluan umat Islam. ${ }^{6}$

Dalam rangka melihat nilai Islam dalam peraturan perundang-undangan, Penulis mencoba memetakan nilai-nilai Islam yang terkandung dalam Undang-Undang Nomor 4 Tahun 2009 dalam materik berikut ini:

\section{Matrik Nilai-Nilai Islam Dalam Undang-Undang Pertambangan Mineral dan Batubara}

\begin{tabular}{|c|c|}
\hline Nilai-Nilai Islam & Ketentuan dalam Undang-Undang \\
\hline$(1)$ & $(2)$ \\
\hline Pemeliharaan & $\begin{array}{l}\text { - Menimbang huruf (a) Mineral dan batubara sebagai karunia Tuhan Yang Maha Esa yang } \\
\text { Dikelola Oleh Negara; } \\
\text { - Asas pengelolaan secara partisipatif, transparansi, dan akuntabilitas (Pasal } 2 \text { huruf (c); } \\
\text { - menjamin kepastian hukum dalam penyelenggaraan kegiatan usaha pertambangan mineral } \\
\text { dan batubara (Pasal } 3 \text { huruf f). } \\
\text { - Mineral dan batubara sebagai sumber daya alam yang tak terbarukan merupakan kekayaan } \\
\text { nasional yang dikuasai oleh negara untuk sebesar-besar kesejahteraan rakyat (Pasal } 4 \text { ayat } \\
\text { (1) } \\
\text { - Kemudian kewenangan pengelolaan oleh pemerintah baik menetapkan kebijakan dan } \\
\text { - Pembuatan peraturan perundang-undangan (Pasal } 6 \text { sampai dengan Pasal 8) }\end{array}$ \\
\hline Konservasi & $\begin{array}{l}\text { - Pasal } 1 \text { angka } 26 \text { memuat nilai Konservasi yaitu Reklamasi untuk menata, memulihkan, dan } \\
\text { memperbaiki kualitas lingkungan dan ekosistem agar dapat berfungsi kembali sesuai } \\
\text { peruntukannya; }\end{array}$ \\
\hline $\begin{array}{l}\text { Harmonisasi Antar } \\
\text { Sumber Daya Alam }\end{array}$ & $\begin{array}{l}\text { - Penetapan WP sebagaimana dimaksud dalam Pasal } 9 \text { ayat (2) dilaksanakan: secara terpadu } \\
\text { dengan memperhatikan pendapat dari instansi pemerintah terkait, masyarakat, dan dengan } \\
\text { mempertimbangkan aspek ekologi, ekonomi, dan sosial budaya, serta berwawasan } \\
\text { lingkungan (Pasal 10); } \\
\text { - Penggunaan Tanah untuk Kegiatan Usaha Pertambangan (Pasal } 134 \mathrm{~s} / \mathrm{d} 138 \text { ) }\end{array}$ \\
\hline Keberlanjutan & $\begin{array}{l}\text { - Bagian Menimbang huruf (b) dan (c) Pembangunan Daerah secara berkelanjutan; } \\
\text { - Asas berkelanjutan dan berwawasan lingkungan (Pasal } 2 \text { huruf (d). (penjelasan asas ini } \\
\text { adalah asas yang secara terencanamengintegrasikan dimensi ekonomi, lingkungan, dan } \\
\text { sosialbudaya dalam keseluruhan usaha pertambangan mineral dan batubara untuk } \\
\text { mewujudkan kesejahteraan masa kini dan masa mendatang. } \\
\text { - Tujuan menjamin manfaat pertambangan mineral dan batubara secara berkelanjutan dan } \\
\text { berwawasan lingkungan hidup (Pasal } 3 \text { huruf b); } \\
\text { - Wilayah Pencadangan Negara (Pasal } 27 \text { ayat (1)) }\end{array}$ \\
\hline Kesejahteraan & $\begin{array}{l}\text { - Menimbang huruf (a) Mencapai Kemakmuran dan Kesejahteraan; } \\
\text { - Dikelola dengan asas manfaat (Pasal } 2 \text { huruf (a); } \\
\text { - Dikelola dengan asas keberpihakan kepada kepentingan bangsa; (Pasal } 2 \text { huruf b); } \\
\text { - meningkatkan pendapatan masyarakat lokal, daerah, dan negara, serta menciptakan lapangan } \\
\text { kerja untuk sebesar besar kesejahteraan rakyat (Pasal } 3 \text { huruf d); }\end{array}$ \\
\hline $\begin{array}{l}\text { Keadilan dan } \\
\text { Keseimbangan }\end{array}$ & $\begin{array}{l}\text { - Menimbang huruf (a) Secara Keadilan; } \\
\text { - Dikelola dengan asas keadilan dan keseimbangan (Pasal } 2 \text { huruf (a); }\end{array}$ \\
\hline
\end{tabular}

\footnotetext{
${ }^{6}$ Muhammad Daud Ali. 2002. Hukum Islam. Jakarta: Rajawali Pers. hlm.245
} 
Berdasarkan hasil pengkajian penulis dalam perspektif Hukum Islam terhadap Undang-Undang Nomor 4 Tahun 2009 tentang Pertambangan Mineral dan Batubara. Ada beberapa nilai-nilai Islam yang terkandung dalam Undang-Undang tersebut yaitu: Pertama kewajiban pemeliharaan, yang tercantum dalam bagian pertimbangan huruf (a), bahwa pertambangan mineral dan batubara sebagai karunia Allah swt, hal ini telah ditegaskan oleh Allah swt dalam Surah Al-Baqarah (2:29) yaitu "Dia-lah Allah yang menjadikan segala yang ada di bumi untuk kamu dan Dia berkehendak menuju langit, lalu dijadikan-Nya tujuh langit. Dan Dia Maha Mengetahui segala sesuatu”. Selanjutnya firman Allah swt dalam Surah Al Baqarah (2:255) yaitu "Allah, tidak ada Tuhan (yang berhak disembah) melainkan Dia Yang Hidup kekal lagi terus-menerus mengurus (makhlukNya), tidak mengantuk dan tidak tidur. KepunyaanNya apa yang di langit dan di bumi..." Dalam surah As Sajdah (32:4) dijelaskan bahwa "Allah-lah yang menciptakan langit dan bumi dan apa yang ada diantara keduanya dalam enam hari..." Kemudian kewajiban Negara mengelola sehingga tidak boleh merusaknya hal ini ditegaskan Allah dalam surah Al-Baqarah (2:30) yaitu "Ingatlah ketika Tuhanmu berfirman kepada para Malaikat :"Sesungguhnya Aku hendak menjadikan seorang Khalifah di muka bumi". Mereka berkata: "Mengapa engkau hendak menjadikan (khalifah) dibumi itu orang yang akan membuat kerusakan padanya dan menumpahkan darah, padahal kami senantiasa bertasbih dengan memuji Engkau dan mensucikan Engkau?" Tuhan berfirman "Sesungguhnya Aku mengetahui apa yang tidak kamu ketahui". Nilai kewajiban memelihara ini terdapat dalam Undang-Undang Nomor 4 Tahun 2009 dicantumkannya asas pengelolaan secara partisipatif, transparansi, dan akuntabilitas dalam Pasal 2 huruf (c), kemudian menjamin kepastian hukum dalam penyelenggaraan kegiatan usaha pertambangan mineral dan batubara terdapat dalam Pasal 3 huruf (f). Untuk mewujudkan nilai pemeliharaan ini dicantumkan dalam Pasal 6 sampai dengan Pasal 8 yaitu kewenangan pengelolaan oleh pemerintah baik menetapkan kebijakan dan pembuatan peraturan perundang-undangan. Perintah memelihara dan melarang melakukan kerusakan telah

Kedua, Nilai konservasi yaitu dalam bentuk reklamasi menata kembali lahan yang telah digali yang terdapat dalam Pasal 1 angka 26 yaitu Reklamasi untuk menata, memulihkan, dan memperbaiki kualitas lingkungan dan ekosistem agar dapat berfungsi kembali sesuai peruntukannya, hal ini sinkron dengan firman Allah swt untuk melarang melakukan kerusakan di muka bumi dan dam kembali kepada jalan yang benar sebagaimana firman Allah swt dalam surah Ar Ruum (30:41) yaitu:" Telah Nampak kerusakan di darat dan di laut disebabkan karena perbuatan tangan manusia, supaya Allah merasakan kepada mereka sebahagian dari (akibat) perbuatan mereka, agar mereka kembali ke jalan yang benar". Inilah perwujudan keseimbangan alam.

Ketiga, Nilai Harmonisasi antar Sumber Daya Alam, Undang-Undang Nomor 4 Tahun 2009 tidak ada mencantumkan secara jelas mengenai harmonisasi antar sumber daya alam. Secara tersirat harmonisasi terlihat dalam pembagian wilayah pertambangan 
yaitu dalam Pasal 10 yaitu Penetapan Wilayah Pertambangan sebagaimana dimaksud dalam Pasal 9 ayat (2) dilaksanakan: secara terpadu dengan memperhatikan pendapat dari instansi pemerintah terkait, masyarakat, dan dengan mempertimbangkan aspek ekologi, ekonomi, dan sosial budaya, serta berwawasan lingkungan. Terjadinya bencana alam saat ini baik tanah longsor, banjir, bencana kekeringan dan lain-lain karena akibat perbuatan manusia yang tidak harmonis dengan alam, firman Allah swt alam surah Ar Ruum (21: ayat 41) "Telah Nampak kerusakan di darat dan di laut disebabkan karena perbuatan tangan manusia, supaya Allah merasakan kepada mereka sebagian dari (akibat) perbuatan mereka, agar mereka kembali (ke jalan yang benar)". Yaitu kembali kepada aturan Allah swt, karena harmonisasi alam ini tercipta karena mengikuti hukum alam (sunnatullah) dengan mematuhi perintah Allah swt.

Keempat, nilai keberlanjutan untuk generasi mendatang. Dalam suatu wilayah Tuhan menciptakan Sumber Daya Manusia, kemudian untuk mendukung Sumber Daya Manusia hidup Tuhan ciptakan Sumber Daya Alam, kemudian dalam pemanfaatan itu diperlukan Sumber Daya Ekologi termasuk teknlogi, dalam pemanfaatannya diperlukan sumber daya social, untuk sumber daya social ini yang sulit di Indonesia. Saat ini sumber daya social kurag kondusif hal ini karena karakter masyarakatnya yang suka tersinggung, kerap terjadi konflik, kekerasan, sengketa dan lain-lain. Kemudian ada sumber daya budaya perlahan-lahan mulai terkikis oleh arus modernisasi dan globalisasi. Semuanya adalah satu kesatuan dalam tatanan. ${ }^{7}$ Undang-Undang Nomor 4 Tahun 2009 memuat nilai keberlanjutan yaitu pada bagian menimbang huruf (b) dan (c) Pembangunan Daerah secara berkelanjutan. Kemudian juga dalam Pasal 2 huruf (d) mengenai asas berkelanjutan dan berwawasan lingkungan. Penjelasan asas ini adalah asas yang secara terencana mengintegrasikan dimensi ekonomi, lingkungan, dan social budaya dalam keseluruhan usaha pertambangan mineral dan batubara untuk mewujudkan kesejahteraan masa kini dan masa mendatang. Imam Ibnu Katsir dalam kitab tafsirnya menjelaskan azab Allah swt akan menimpa suatu bangsa yang berbuat dzalim dan semena-mena dan dalam kesempatan lain Al-Qur'an menjelaskan dalam Surah An-Nahl ayat 112 sebagai berikut "Dan Allah telah membuat perumpaaan (dengan) sebuah negeri yang dahulunya aman lagi tenteram, rezekinya datang kepadanya melimpah ruah dari segenap tempat, tetapi (penduduknya) mengingkari nikmat-nikmat Allah; karena Allah merasakan kepada mereka pakaian kelaparan dan ketakutan, disebabkan apa yang mereka perbuat". Begitu juga dalam Surah Yunus ayat 13 Allah swt berfirman "Dan sesungguhnya Kami telah membinasakan umat-umat sebelum kamu, ketika mereka berbuat kedzaliman”. Jadi kekayaan alam yang diberikan Allah saat ini harus dipelihara dan dijaga untuk keberlanjutan generasi berikutnya.

Kelima, nilai Kesejahteraan dimana pertambangan dan mineral diperuntukkan untuk kesejahteraan rakyat. Dalam Undang-Undang Nomor 4 Tahun 2009 Nilai ini

\footnotetext{
${ }^{7}$ Abrar Saleng. 2013. "Nilai-Nilai Hukum Islam Dalam Pengelolaan Sumber Daya Alam". Slide Hand Out Kuliah Hukum Islam. Makassar: Program Doktor Ilmu Hukum Universitas Hasanuddin.hlm 12.
} 
terdapat dalam bagian menimbang huruf (a) yaitu untuk mencapai kemakmuran dan kesejahteraan. Juga dalam Pasal 2 huruf (a) yang pengelolaan dikelola dengan asas manfaat (Pasal 2 huruf (a). Juga dicantumkan dalam Pasal 2 huruf (b) dikelola dengan asas keberpihakan kepada kepentingan bangsa. Berikutnya dalam Pasal 3 huruf (d) yaitu meningkatkan pendapatan masyarakat lokal, daerah, dan negara, serta menciptakan lapangan kerja untuk sebesar besar kesejahteraan rakyat, namun dari berbagai penelitian disertasi mahasiswa program Doktoral, ada fenomena masyarakat di daerah areal tambang justru mengalami kemiskinan. Padahal Al Qur'an menyebutkan mengenai barakah yang diberikan Allah kepada suatu negeri yang beriman dan bertaqwa, hal ini ditegaskan surah Al A'raf (7:96) yaitu " Dan sekiranya penduduk negeri beriman dan bertaqwa, pasti kami akan melimpahkan kepada mereka berkah dari langit dan bumi, tetapi ternyata mereka mendustakan (ayat-ayat Kami), maka Kami siksa mereka sesuai dengan apa yang telah mereka kerjakan".

Keenam, nilai Keadilan dan Keseimbangan. Undang-Undang Nomor 4 Tahun 2009 menegaskan mengenai nilai keadilan dalam pengelolaan Pertambangan Mineral dan batubara, yakni terdapat dalam bagian menimbang huruf (a) Secara Keadilan, kemudian pada Pasal 2 huruf (a) yaitu dikelola dengan asas keadilan dan keseimbangan. Kita wajib menjaga keseimbangan alam semesta agar tercipta kehidupan, sebagaimana firman Allah swt dalam surah Al Anbiya ayat 30 yaitu "Dan dari air Kami jadikan segala sesuatu yang hidup". Rasulullah mengingatkan salah seorang sahabat untuk merawat alam disekitarnya. Diriwayatkan bahwa Rasulullah melihat Sa'ad bin Abi Waqas sedang berwudlu, ia bersabda " Janganlah berlebih-lebihan”, Sa'ad bin Abi Waqas bertanya” "Apakah dalam menggunakan air ada istilah berlebih-lebihan?”, Rasul menjawab: "Ada, walaupun kamu berada di sungai yang mengalir". (Hadits Riwayat Ibnu Majah). Jadi kita harus memelihara dan menjaga kesimbangan dan kelestarian alam sementa, agar nikmat Allah dapat dirasakan umat kemudian. Mari kita renungkan firman Allah swt dalam surah Al-Maidah (5) ayat 50) "Apakah (sistem) hukum jahiliyah yang mereka kehendaki. (Sistem) hukum siapakah yang lebih baik dari pada (sistem) hukum Allah bagi orang-orang yang yakin".

Nilai-nilai tersebut diatur dalam pertimbangan, asas dan tujuan, namun pengaturan berikutnya justru nilai liberalisasi dimana diberikan kebebasan kepada pihak lain (swasta) mengelola pertambangan, dengan diberikannya izin kepada perusahaan badan usaha maupun juga kepada perorangan, Negara hanya sebagai regulator saja. Padahal Indonesia memiliki banyak cadangan pertambangan, seperti digambarkan dalam cekungan Batubara di Indonesia yang dimiliki oleh Kementerian ESDM berikut ini: 


\section{CEKUNGAN BATUBARA DAN CBM INDONESIA}

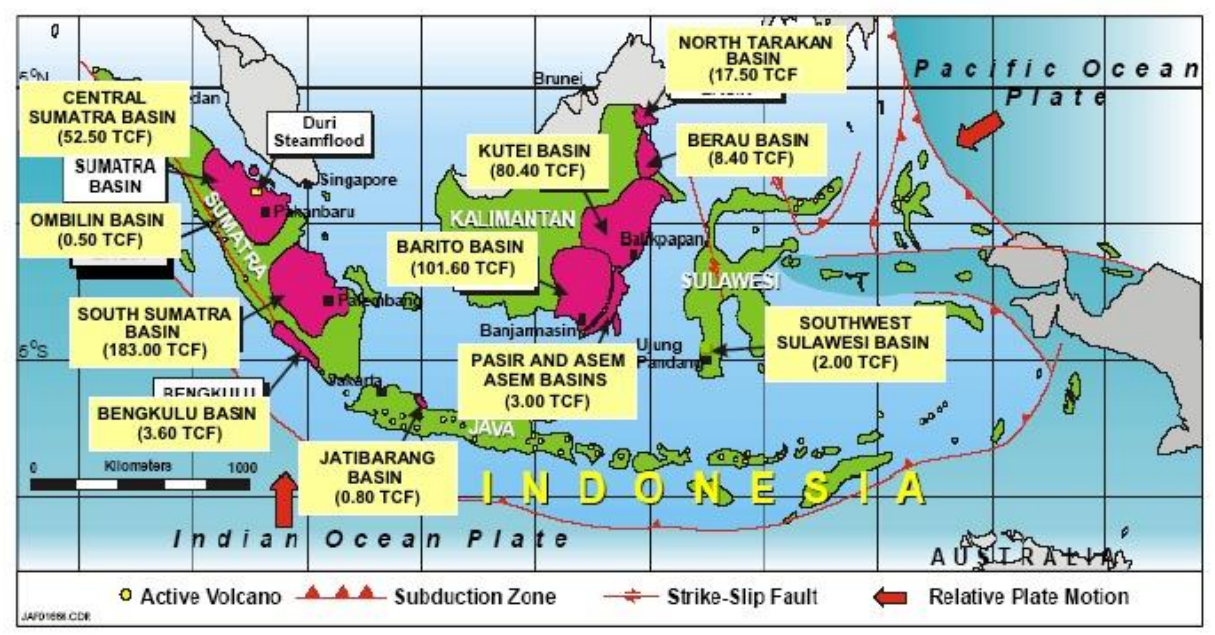

TOTAL CBM RESOURCES $=453.30 \mathrm{TCF}$

Contoh: Royalti batubara hanya Rp 85milyar sedangkan ekspornya mencapai US\$ 4,4 milyar tahun lalu (setara Rp 40 trilyun) ${ }^{8}$. Ini membuktikan bahwa justru keberadaan tambang tidak memberikan kesejahteraan kepada rakyat, dan terjadi kerusakan lingkungan dan lain-lain yang justru jauh dari nilai-nilai Islam.

Arah hukum nasional Indonesia tidak mengarah kepada ideologi Negara yaitu Pancasila. Pada masa Orde Lama kearah hukum sosialis dengan ide Nasionalis, Agama, Komunis (NASAKOM), pada Orde Baru kearah hukum kapitalis dan pada Era Reformasi kearah hukum Liberal. Arah hukum liberal yaitu perlahan-lahan mengurangi bahkan melepaskan tanggung jawab Negara untuk turut serta dalam mensejahterakan rakyat.

Begitu juga dengan Undang-Undang Nomor 04 Tahun 2009 tentang Mineral dan Batubara (UU Minerba) menggantikan Undang-Undang Nomor 11 Tahun 1967 tentang Pokok-Pokok Pertambangan, melengkapi lepasnya peran pemerintah dari segala hal mengenai Pengelolaan Sumber Daya Alam yang diserahkan kepada para pemilik modal/swasta nasional maupun asing. Sehingga nilai yang terkandung di dalam UndangUndang Mineral dan Batubara tersebut justru tidak menggambarkan nilai hukum Islam melainkan nilai hukum liberal, dimana masyarakat dalam hal ini pengusaha diberi kesempatan sebesar-besarnya untuk mengekploitasi pertambangan batubara di Indonesia.

\section{B. Pengelolaan Pertambangan Dalam Hukum Islam}

${ }^{8}$ Hidayatullah Muttaqien. 2010. Konsepsi Ekonomi Islam Untuk Pengembangan Ekonomi Daerah. Bahan Kuliah Slide Hand Out . Banjarmasin: Fakultas Ekonomi Universitas Lambung Mangkurat. hlm. 8 
Keberadaan Undang-Undang Nomor 4 Tahun 2009 tentang Pertambangan Mineral dan Batubara, yang dalam pengelolaannya menegaskan mengenai pengelola tambang adalah negara yang kemudian negara memberikan kewenangan kepada Pemerintah. Berikutnya pemerintah diberikan kewenangan memberikan pembagian wilayah pertambangan dan memberikan izin kepada pihak lain (swasta) baik berbentuk perusahaan berbadan hukum mamupun perorangan untuk menggarap pertambangan mineral dan batubara. Akhirnya pertambangan mineral dan batubara bukannya memberikan kemakmuran dan kesejahteraan justru muncul sebuah fenomena setiap ada pertambangan, disitu juga muncul kemiskinan dan terjadi kerusakan lingkungan. Lalu pengelolaan tambang menurut Islam, berikut ini Penulis uraikan.

Hukum Al Qur'an jauh melebihi lingkup pembuatan hukum positivis dan meliputi setiap aspek kehidupan, termasuk kehidupan akhirat, bidang tersebut jauh lebih luas daripada yang hendak dijangkau oleh studi-studi hukum konvensional. ${ }^{9}$ Pemberlakuan hukum Islam oleh negara sesungguhnya merupakan perkara yang sudah diketahui kewajibannya dalam Islam (ma'lumun min al-dini bi al- dharurati) sebagaimana telah diketahuinya kewajiban shalat, shaum, zakat, haji dan sebagainya. Bahkan sejatinya, berdirinya suatu institusi (negara) dengan segenap struktur dan wewenangnya dalam kacamata Islam memang untuk menyukseskan pelaksanaan hidup bermasyarakat dalam kerangka beribadah kepada Allah SWT. Maka perjuangan bagi penegakan syariat Islam bagi seorang muslim juga merupakan kemestian, diyakini bahwa tidak akan pernah ada kemuliaan kecuali dengan Islam, dan tidak ada Islam kecuali dengan syariah dan tidak adanya syariah kecuali dengan adanya daulah (negara). ${ }^{10}$

Hukum Islam adalah salah satu pilar utama Negara dalam membangun masyarakat, dan hukum sendiri diperuntukkan untuk masyarakat. Di manapun mereka berada selalu memerlukan hukum dan undang-undang untuk mengatur hubungan diantara mereka. ${ }^{11}$

Jadi filosofis hukum Islam itu bahwa dalam beragama Islam manusia tidak bisa dipisahkan dengan kehidupan, sehingga Syariat Islam (Hukum Islam) yang menjadi ruhnya adalah bahwa hukum itu dibuat oleh Allah SWT dan dan bukti ketaatan manusia adalah dengan melaksanakan seluruh perintah Alah SWT ( Syariat Islam/Hukum Islam, jadi dengan filosofis ruh idrak sillahbillah (kesadaran akan hubungannya dengan Allah).

Hukum berbasis spritual adalah kembali kepada Aqidah Islam sebagai lingkaran dari inti hukum yang menarik lingkaran teori hukum, dogmatik hukum dan fakta hukum.

\footnotetext{
${ }^{9}$ Wemer Menski, 2012. Perbandingan Hukum Dalam Konteks Global, Sistem Eropa, Asia dan Afrika (Comparative Law In a Global Context: UK:Cambridge University Press:2008). Bandung : Nusamedia. hlm.395

${ }^{10}$ Abdul Qadim Zallum. 2002. Sistem Pemerintahan Islam. (Trans). Taqiyuddin An-Nabhani. dalam Kitab Nidhomul Hukmi Fil Islam. Jakarta: Pustaka Tariqul Izzah. hlm. 30.

${ }^{11}$ Yusuf Qardhawi. 2003. Masyarakat berbasis Syariah Islam. Hukum, Perekonomian, Perempuan. Jakarta: Intermedia . hlm.14
} 
Dalam Islam mengenal sistem hukum yaitu dengan sebutan syariat ataupun syariah. Secara bahasa, syariat (al-syari'ah) berarti sumber air minum (mawrid al-ma-li al istisqa) atau jalan lurus (at-thariq al-mustakim). Sedangkan menurut istilah : syariah bermakna :Peraturan-peraturan/perundang-undangan yang diturunkan Allah SWT melalui Rasulullah Muhammad SAW untuk seluruh umat manusia baik menyangkut masalah ibadah, akhlak, makanan, minuman, pakaian maupun muamalah (hubungan interaksi sesama manusia dalam berbagai aspek kehidupan) guna meraih kebahagiaan di dunia dan akhirat. ${ }^{12}$ Jadi setiap hukum yang digali dari sumber-sumber hukum Islam (AlQur'an, As Sunnah, Ijma Shabat, Qiyas) merupakan hukum syariat (al-ahkam asy syar'iyyah) atau bisa disebut syariat saja. Karenanya, ketika orang Beriman (beraqidah Islam), maka konsekuwensi iman adalah ketaatan kepada Allah SWT dengan melaksanakan syariat Islam mencakup: Syariat yang mengatur hubungan dengan Allah (ibadah mahdoh) seperti sholat, puasa, zakat, haji; Syariat yang mengatur hubungan manusia dengan dirinya seperti makan, minum, berpakaian, akhlaq; serta Syariat yang mengatur hubungan manusia dengan manusia lainnya seperti pemerintaha, politik, ekonomi, pendidikan, peradilan/uqubah/system sanksi dan sosial/budaya. Jadi yang dimaksud syariat Islam bukanlah sekedar sanksi hukum pidana (hudud wal jinayat) semata, melainkan seluruh hukum bagi semua aspek kehidupan. Berikut ini penulis buat skemanya:

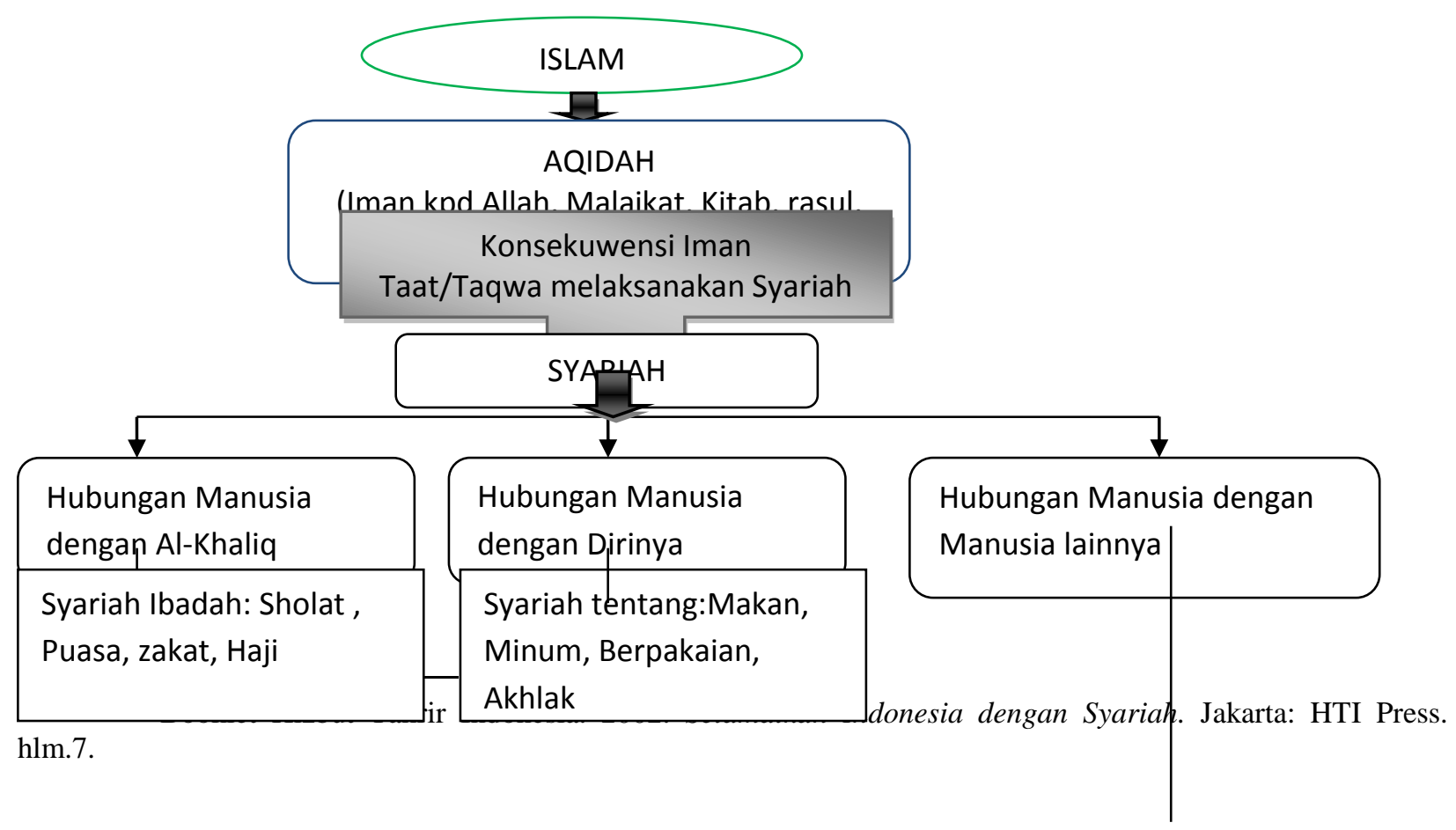




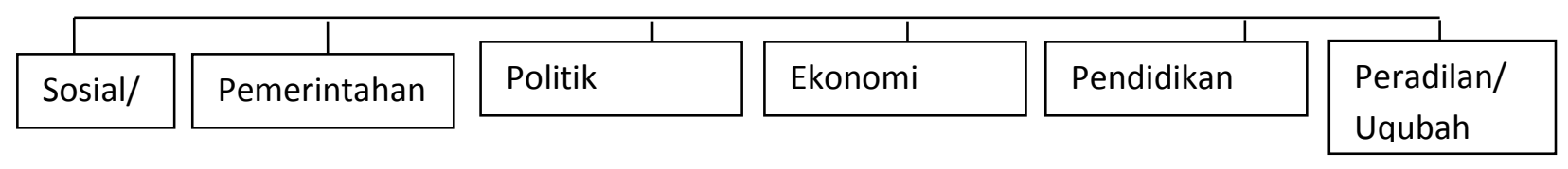

Tidak perlu diperdebatkan lagi bahwa apakah Islam memiliki sistem hukum atau tidak, atau perdebatan apakah ada Negara Islam atau tidak. Karena Syariat Islam itu telah dilaksanakan oleh Rasul tentu dalam sebuah Negara yang beliau jalankan di Madinah al Munawarah. Negara berarti sebagai suatu organisasi yang mengatur aktivitas-aktivitas individu dalam hubungannya dengan masyarakat dimana negara itu bertindak sebagai kekuatan kolektif melalui perangkat peraturan, istitusi, dan hukum tertentu. ${ }^{13}$

Begitu juga dengan Syariat Islam juga dijalankan oleh Negara. Kembali pada pengaturan sektor publik khususnya pengaturan Hak kepemilikan Umum ini masuk dalam syariat Islam yang mengatur hubungan manusia dengan manusia lainnya bidang ekonomi. Dalam Islam dikelompokkan dalam 3 (tiga kelompok) yaitu: ${ }^{14}$

Kelompok Pertama harta yang merupakan fasilitas umum yang jika tidak ada akan terjadi sengketa dalam mencarinya. Rasulullah saw bersabda "Al muslimuna Syuraka'a ufi salasin fil kalaa'i wal maa'i wannari” artinya "Kaum Muslim berserikat dalam tiga perkara yaitu padang rumput, air dan api” (HR Abu Dawud, Ahmad, alBaihaqi dan Ibn Abi Syaibah). ${ }^{15}$ As-sarakhsi (w.483 H) dalam Al-Mabsuth menjelaskan, "di dalam hadis ini terdapat penetapan berserikatnya manusia baik Muslim maupun kafir, dalam ketiga hal itu tidak seorangpun boleh menghalangi seseorang dari pemanfaatan itu. Statusnya seperti pemanfaatan jalan umum untuk berjalan di jalan itu. Maksud mereka

${ }^{13}$ M.Hadin Muhjad. 1996. Filsafat Hukum (Dasar-dsar \& Refleksinya), Banjarmasin: Fakultas Hukum Unlam. Hal. 28.

${ }^{14}$ Taqiyuddin An Nabhani.2012. Nizham al-Iqtishadi fi al-Islam. Cet.VI. Beirut.Libanon. Penerbit. Dar-AlUmmah.hlm.300. Lihat juga Booklet Hizbut Tahrir Indonesia. Ibid. Hadits ini shahih (lihat : Ibn Abdil Bar, alIsti'ab,IV/1635:Ibn Hajar al-Ashqalani. 1964. Talkish al-Habir, iii/65, Madinah al Munawarah; al-Albani, Irwa alGhalil.vi/6-9, Maktab al-Islami, Beirut.cet ii.1405/1985). Abu Hatim mengatakan: Abu Hidasy tidak berjumpa dengan Nabi saw dan ia disebutkan dalam riwayat Abu Dawud adalah Hibban bin Zaid asy-Syar'abi. Ia seorang tabi'un yang ma'ruf-sudah dikenal (Talkhis Habir,iii/65). Dalam riwayat-riwayat tersebut, Abu Hidasy berkata bahwa ia mendengarnya dari salah seorang sahabat- dalam riwayat Abu Dawud dari salah seorang Muhajirin, tapi tidak ia sebutkan namanya. Tidak ada penyebutan nama sahabat tidak membahayakan sanadnya, sebab menurut ahlus sunah semua Sahabat adalah tsiqat, apalagi dalam sebagian riwayat disebutkan Sahabat itu adlaah Muhajirin (Lihat: Az-Zaila'I, Nash bar- rayah.iv/352. Dar al-Hadits. Mesir.1357; Irwa' al-Ghalil.vi/6-9

${ }^{15}$ Ibid. Hadits ini shahih (lihat : Ibn Abdil Bar, al-Isti'ab,IV/1635:Ibn Hajar al-Ashqalani. 1964. Talkish alHabir, iii/65, Madinah al Munawarah; al-Albani, Irwa al-Ghalil.vi/6-9, Maktab al-Islami, Beirut.cet ii.1405/1985). Abu Hatim mengatakan: Abu Hidasy tidak berjumpa dengan Nabi saw dan ia disebutkan dalam riwayat Abu Dawud adalah Hibban bin Zaid asy-Syar'abi. Ia seorang tabi'un yang ma'ruf-sudah dikenal (Talkhis Habir,iii/65). Dalam riwayat-riwayat tersebut, Abu Hidasy berkata bahwa ia mendengarnya dari salah seorang sahabat- dalam riwayat Abu Dawud dari salah seorang Muhajirin, tapi tidak ia sebutkan namanya. Tidak ada penyebutan nama sahabat tidak membahayakan sanadnya, sebab menurut ahlus sunah semua Sahabat adalah tsiqat, apalagi dalam sebagian riwayat disebutkan Sahabat itu adlaah Muhajirin (Lihat: Az-Zaila'I, Nash bar- rayah.iv/352. Dar al-Hadits. Mesir.1357; Irwa' al-Ghalil.vi/6-9. 
dari frasa syarikah (bayna an-nãs) berserikat di antara manusia adalah penjelasan ketentuan pokok kebolehan dan kesetaraan (musãwah) di antara manusia dalam hal pemanfaatan, bukan karena ketiganya milik mereka. Jadi air di lembah itu bukan milik seseorang. ${ }^{16}$

Pelaksanaan syariah oleh negara sesungguhnya merupakan perkara yang sudah diketahui kewajibannya dalam Islam (ma'lumun min al-dini bi al- dharurati) sebagaimana telah diketahuinya kewajiban shalat, shaum, zakat, haji dan sebagainya. Bahkan sejatinya, berdirinya suatu institusi (negara) dengan segenap struktur dan wewenangnya dalam kacamata Islam memang untuk menyukseskan pelaksanaan hidup bermasyarakat dalam kerangka beribadah kepada Allah SWT. Maka perjuangan bagi penegakan syariat Islam bagi seorang muslim juga merupakan kemestian, diyakini bahwa tidak akan pernah ada kemuliaan kecuali dengan Islam, dan tidak ada Islam kecuali dengan syariah dan tidak adanya syariah kecuali dengan adanya daulah (negara). ${ }^{17}$

Meskipun demikian Rasulullah membolehkan sumur di Thaif dan Khaibar dimiliki oleh individu untuk menyirami kebun. Rasulullah saw juga membolehkan Utsman ra. Membeli sumur dari seorang Yahudi di Madinah yang kemudian ia wakafkan, sehingga bisa dipahami bahwa berserikatnya masyarakat dalam air, padang rumput dan api itu bukan karena zatnya, tetapi keberadaannya yang dibutuhkan oleh masyarakat, yang jika tidak ada akan terjadi perselisihan atau masalah dalam mencarinya. Dengan demikian, sifat ini menjadi 'illat istinbãthan perserikatan manusia dalam tiga hal itu. Oleh sebab itu masyarakat berserikat bukan hanya pada fasilitas umum yang berupa air, api (mencakup sumber energi) dan padang rumput saja, tetapi juga dalam semua harta yang memenuhi sifat sebagai fasilitas umum yang keberadaannya dibutuhkan secara bersama yang jika tidak ada akan terjadi perselisihan dalam mencarinya.

Kelompok Kedua, barang tambang yang depositnya besar. Abyadh bin Hammal ra berkata:

"Ia pernah datang kepada Rasulullah saw dan meminta diberi tambang garam. Lalu Beliau memberikannya. Ketika ia pergi, seorang laki-laki yang ada di majelis itu berkata,"Tahukah Anda apa yang Anda berikan, tidak lain Andan memberinya laksana air yang terus mengalir" Ia berkata Rasul lalu menariknya dari Abyadh bin Hammal" (HR Abu Dawud, at-Tirmidzi, Ibn Hibban). ${ }^{18}$

16 As-Sarakhsi.1406H/1986M. al-Mabsũth.xxiii. Dar al- Ma'rifah. Beirut.hlm.164

${ }^{17}$ Abdul Qadim Zallum. 2002. Op.Cit.hlm. 31.

18 Booklet. Loc.Cit. At Tirmidzi menghasankannya, Ibn Hibban menshahihkan, Ibnul Qaththan mendlo'ifkan (as Shon'ãnŷ (w.1276 H). Fathul Ghaffãr, 3/1284), hadits ini diamalkan ahlul 'ilmi dari kalangan sahabat (tahqiq Abdul Qadir Arna’uth atas kitab Jãmi’ul Ushul, 10/578 karya Ibnul Atsir (w.606 H). 
Riwayat ini berkaitan dengan barang tambang garam, bukan ragam itu sendiri, dalam riwayat an-nasal dari Amru bin Yahya bin Qais jelas disebutkan ma'din al-milh ( tambang garam). Awalnya rasul memberikan tambang garam itu kepada Abyadh. Namun, ketika beliau diberi tahu tambang itu seperti al-mã'a al'iddu, maka Rasul menariknya kembali dari Abyadh. Al-mã'a al'iddu adalah yang terus menerus mengalir tidak terputus, artinya cadangannya besar sekali. Jadi, sebab ('illat) penarikan tambang itu adalah keberadaannya yang terus menerus mengalir tak terputus, yaitu cadangannya besar sekali. Karena itu, semua barang tambang yang cadangannya besar sekali, baik barang tambang permukaan ataupun di perut bumi, baik berupa benda padat seperti besi, emas, perak dan sebagainya atau berupa cair seperti minyak bumi maupun berupa gas bumi, maka semua itu termasuk dalam cakupan di atas, yaitu merupakan milik umum.

Kelompok Ketiga, harta yang karena tabiat pembentukannya menghalangi untuk dimiliki individu seperti sungai, danau, laut, jalan umum, lapangan, masjid dan sebagainya, yaitu harta-harta yang mencakup kemanfaatan umum. Meski harta milik publik jenis ketiga ini seperti jenis pertama, yaitu merupakan fasilitas umum, jenis ini berbeda dari sisi sifatnya, yaitu bahwa tabiat pembentukannya menghalangi jenis harta ini untuk dimiliki oleh pribadi. Ini jelas berbeda dari jenis pertama yang zatnya, misalnya air boleh dimiliki individu, namun individu dilarang memilikinya jika dibutuhkan oleh masyarakat. Jadi meskipun dalil harta kelompok keiga ini adalah berlakunya 'illat syar'iyyah yaitu sebab keberadaannya sebagai fasilitas umum yang dibutuhkan oleh masyarakat, esensi zatnya menunjukkannya sebagai milik umum dan tidak boleh dimiliki secara pribadi. Karena itu, kelompok harta ini menjadi kelompok tersendiri yang dibedakan dari kelompok pertama.

Berdasarkan pemaparan di atas maka, Negara wajib memberikan jaminan atas pemenuhan atas seluruh kebutuhan pokok individu dan masyarakat serta menjamin kemungkinan pemenuhan berbagai kebutuhan sekunder dan tersier sesuai dengan kemampuan bersangkutan. Untuk menjamin kebutuhan tersebut Syariat Islam yang mengatur bidang ekonomi mengenai kepemilikan umum seperti tambang, migas, laut dan hutan wajib dikelalo oleh Negara dan tidak boleh diserahkan kepada swasta apalagi asing. Hal ini mengoptimalkan pendapatan Negara yang danan diperuntukkan untuk kepentingan umum seperti pendidikan gratis, kesehatan gratis, dana pengadaan fasilitas umum seperti pasar, jembatan, jalan dan lain-lain.

Jika semua kepemilikan umum dikuasai dan dikelola oleh Negara, tentu akan tersedia dana yang mencukupi untuk memenuhi kebutuhan rakyat. Misalnya untuk sektor pertambangan di Indonesia diprediksi mendapat pemasukan sebesar Rp 691 triliun pertahun. Sektor kelautan dengan potensi sekitar US\$ 82 miliar atau Rp738 triliun pertahun akan diperoleh minimal sekitar Rp 73 triliun. Disektor kehutanan dengan luas hutan sekitar 90 juta hektar dengan pengelolaan secara lestari (dengan tebang berjenjang/tidak tebang seluruhnya dan reboisasi/tanam kembali) diperkirakan diperoleh 
penerimaan sekitar Rp 1.800 triliun/tahun. ${ }^{19}$ Dengan pembiayaan seperti ini dengan pengelolaan yang amanah, sudah cukup memadai untuk mewujudkan kesejahteraan rakyat. Bukti syariat Islam mampu mensejahterakan rakyat dapat dilihat pada masa Khalifah Umar bin Abdul Azis pada masa Beliau menjabat selama 29 bulan, ketika beliau memerintahkan petugas zakat membagikan zakat sampai wilayah Afrika Utara, tidak seorangpun yang mau menerima, karena merasa tidak berhak menerima zakat, karena telah hidup sejahtera, akhirnya Khalifah Umar bin Abdul Azis memerintahkan untuk dibagikan kepada pemuda-pemuda yang belum menikah untuk uang mahar. Jadi sistem pengelolaan sumber daya alam yang merupakan milik umum harus dikelola negara dan dananya diperuntukkan untuk kepentingan umum yang mensejahterakan rakyat. Dengan demikian sistem hukum Islam memberikan kesejahteraan bagi rakyat dan sejarah telah membuktikannya.

\section{PENUTUP}

\section{A. Kesimpulan}

1. Undang-Undang Nomor 4 Tahun 2009 tentang Pertambangan Mineral dan Batubara memuat nilai Islami yaitu Nilai pemeliharaan, nilai konservasi, nilai harmonisasi antara sumber daya alam, nilai keberlanjutan, nilai kesejahteraan dan nilai keadilan dan keseimbangan. Namun dalam pengaturan berikutnya justru menganut nilai liberal yang memberikan kebebasan kepada pihak lain (swasta) untuk menggarap sektor pertambangan mineral dan batubara. Hasilnya dapat kita lihat perusahaan pertambangan yang marak justru tidak memberikan kesejahteraan bagi masyarakat lokal dan berdampak pada kerusakan lingkungan.

2. Pengelolaan pertambangan dalam Islam yaitu dikelompokkan dalam 3 bagian yaitu pertama, harta yang merupakan fasilitas umum yang jika tidak ada akan terjadi sengketa dalam mencarinya, maka ini merupakan harta bersama yang harus dikelola Negara bukan dikelola individu/kelompok. Kelompok kedua, barang tambang yang depositnya besar, ini juga harus dikelola oleh Negara tidak boleh dimiliki oleh individu atau kelompok (baik perorangan maupun badan usaha), namun ketersediaan tambang yang dalam skala kecil dibolehkan individu mengusahakannya/mengelolanya. Kelompok ketiga harta tabiat pembentukannya menghalangi untuk dimiliki individu seperti sungai, danau, laut, jalan umum, lapangan, masjid dan sebagainya, yaitu harta-harta yang mencakup kemanfaatan umum.

19 Arim Nasim.2011.Menyoal Pembatasan Subsidi BBM. http://hizbut-tahrir.or.id/2011/03/02/menyoalpembatasan--subsidi-bbm/diakses tanggal 13 Juni 2013. 


\section{B. Saran}

1. Perlunya sinkronisasi nilai Islam yaitu Nilai pemeliharaan, nilai konservasi, nilai harmonisasi antara sumber daya alam, nilai keberlanjutan, nilai kesejahteraan dan nilai keadilan dan keseimbangan yang ada dalam pertimbangan dan asas-asas dan tujuan dalam Undang-Undang Nomor 4 tahun 2009 ke dalam Pasal-Pasal berikutnya yang mengatur secara teknis.

2. Segi pengelolaan pertambangan perlu mengadopsi mengenai cara pengelolaan pertambangan dalam sistem Islam yang dijalankan oleh Rasulullah saw, sehingga dapat mensejahterakan umat manusia di Indonesia.

3. Perlunya mereview ulang Izin Pertambangan di Indonesia atau paling tidak dapat menegosiasikan kembali pembagian royalty antara perusahan dan Negara sehingga dapat menguntungkan kedua belah pihak.

\section{DAFTAR PUSTAKA}

\section{Buku}

As-Sarakhsi.1406H/1986M. al-Mabsüth.xxiii. Libanon-Beirut:Penerbit Dar al- Ma'rifah.

Abrar Saleng. 2013. "Nilai-Nilai Hukum Islam Dalam Pengelolaan Sumber Daya Alam”. Slide Hand Out Kuliah Hukum Islam. Makassar: Program Doktor Ilmu Hukum Universitas Hasanuddin.

Abdul Qadim Zallum. 2002. Sistem Pemerintahan Islam. (Trans). Taqiyuddin An-Nabhani. dalam Kitab Nidhomul Hukmi Fil Islam. Jakarta: Pustaka Tariqul Izzah.

Booklet Hizbut Tahrir Indonesia. 2002. Selamatkan Indonesia dengan Syariah. Jakarta:HTI Press

Muhammad Daud Ali. 2002. Hukum Islam. Jakarta: Rajawali Pers.

M.Hadin Muhjad. 1996. Filsafat Hukum (Dasar-dasar \& Refleksinya), Banjarmasin: Fakultas Hukum Unlam.

Sunaryati Hartono. 1988. Politik Hukum, Jakarta: YLBHI

Wemer Menski, 2012. Perbandingan Hukum Dalam Konteks Global, Sistem Eropa, Asia dan Afrika (Comparative Law In a Global Context: UK:Cambridge University Press:2008). Bandung : Nusamedia.

Yusuf Qardhawi. 2003. Masyarakat berbasis Syariah Islam. Hukum, Perekonomian, Perempuan. Jakarta: Intermedia

\section{Makalah/Artikel}

Arim Nasim.2011.Menyoal Pembatasan Subsidi BBM. http://hizbuttahrir.or.id/2011/03/02/menyoal-pembatasan--subsidi-bbm / diakses tanggal 13 Juni 2013. 
Buletin Al- Islam. "Mengelola Sumber Daya ALam Secara Islami”. Edisi 75/Th.VIII.Jakarta: HTI.

Hidayatullah Muttaqien. 2010. "Konsepsi Ekonomi Islam Untuk Pengembangan Ekonomi Daerah”. Slide Hand Out . Banjarmasin: Fakultas Ekonomi Universitas Lambung Mangkurat.

Lembaga Dakwah Kampus UNLAM dan Himpunan Mahasiswa Fisika FKIP UNLAM. 2008. "Analisis Potensi Kalimantan Selatan Dalam Peta Energi di Indonesia." Kalimantan Selatan Berdialog.Banjarmasin: Universitas Lambung Mangkurat Banjarmasin. 